\title{
Publication impact in sponge chemical and microbial ecology
}

\author{
Oriol Sacristán-Soriano ${ }^{1,2}$, Mikel A. Becerro ${ }^{1}$ \\ ${ }^{1}$ Centre for Advanced Studies of Blanes (CEAB-CSIC), Accés a la Cala St. Francesc 14, Blanes 17300, Girona, Spain. \\ E-mail: osacriso7@gmail.com \\ ${ }^{2}$ Department of Evolutionary Biology, Ecology and Environmental Sciences, Faculty of Biology, Universitat de Barcelona, \\ Av. Diagonal 643, Barcelona 08028, Spain
}

\begin{abstract}
Summary: It is well known that sponges constitute one of the most prevalent groups in marine benthic communities based on their challenging structural organization, abundance and diversity, and their functional roles in natural communities. The evolutionary success of this group may be explained by the close interaction between sponges and microbes, which dates back to the Precambrian era. This particular symbiosis has become a key factor within sponge research and is an emerging topic of two scientific disciplines: chemical and microbial ecology. This mini-review evaluates the influence of these two disciplines on the general scientific community using a series of bibliometric indicators to ensure objectivity. Our analyses showed that, although sponge chemical ecology has a greater overall impact on the scientific community, both disciplines are cited equally and more frequently than expected. Both research areas show a great impact on applied sciences, but the ecological perspectives of sponge chemistry and microbiology may fall outside the interests of a broader ecological audience. Moreover, we highlight some research topics (e.g. effects of environmental stress) that may require further attention. Hence, sponge chemical and microbial ecology have the opportunity to contribute to broader ecological issues in topics that make sponges particularly important, such as symbiosis.
\end{abstract}

Keywords: Porifera research; natural products; microbiology; symbiosis; h-index; bibliometric indicators.

Impacto de las publicaciones en ecología química y microbiana de esponjas

Resumen: Las esponjas constituyen uno de los grupos predominantes en las comunidades bentónicas marinas gracias a su potencial organización estructural, abundancia, diversidad y a las funciones que desempeñan en las comunidades naturales. El éxito evolutivo de este grupo yace en la estrecha interacción con microorganismos que data del Precámbrico. Esta particular simbiosis se ha convertido en un factor clave en la investigación sobre esponjas y está emergiendo en dos campos como el de la ecología química y microbiana. Esta mini-revisión evalúa la influencia de estas dos disciplinas en la comunidad científica utilizando una serie de indicadores bibliométricos para asegurar la objetividad. Nuestro análisis muestra que aunque la ecología química presenta un mayor impacto global, ambos campos son citados de manera similar y con una frecuencia superior a la esperada. Ambas áreas presentan un gran impacto en ciencias aplicadas, pero las perspectivas ecológicas de las dos disciplinas científicas deben quedar fuera de los intereses generales de la comunidad de ecólogos. Además, señalamos algunas áreas (e.g. efectos del estrés ambiental) que necesitarían mayor atención. Por tanto, la ecología química y microbiana de esponjas tienen la oportunidad de contribuir sobre cuestiones de ecología general con temas que las hace particularmente relevantes, como es la simbiosis.

Palabras clave: investigación en Porifera; productos naturales; microbiología; simbiosis; índice h; indicadores bibliométricos.

Citation/Como citar este artículo: Sacristán-Soriano O., Becerro M.A. 2016. Publication impact in sponge chemical and microbial ecology. Sci. Mar. 80(4): 555-566. doi: http://dx.doi.org/10.3989/scimar.04466.04A

Editor: D. Vaqué.

Received: May 2, 2016. Accepted: July 28, 2016. Published: November 4, 2016.

Copyright: (9) 2016 CSIC. This is an open-access article distributed under the terms of the Creative Commons Attribution (CC-by) Spain 3.0 License. 


\section{INTRODUCTION}

\section{The importance of sponges}

Phylum Porifera (Grant, 1836) are sessile metazoans with a differentiated inhalant and exhalant aquiferous system with external pores. A unidirectional water current is generated through the body to accomplish physiological functions by flagellated cells (choanocytes), usually contained within chambers (Bergquist 1978, Hooper and van Soest 2002). Sponges possess different cell types with mobile and totipotent cells that give this phylum a huge plasticity (Hooper and van Soest 2002). Lacking a tissue grade of construction, sponges can possess two well-differentiated regions, the ectosome (external layer free of choanocytes) and the choanosome (internal region with choanocytes) (Boury-Esnault and Rützler 1997). As the most likely primitive metazoans (Schutze et al. 1999, Halanych 2004, Giribet et al. 2007), their challenging structural organization, physiology for biocalcification and trophic requirements allowed sponges to rapidly colonize different environments and build large sponge reefs during the Paleozoic and Mesozoic eras (Carrera and Botting 2008, Jackson et al. 2010). This phylum was therefore ecologically important in marine benthic communities. To date, sponges are still ecologically important among benthic fauna, although their role as reef builders in modern coral reefs has changed in favour of scleractinian corals (Hooper and van Soest 2002, Jackson et al. 2010). Nonetheless, sponges have demonstrated a great capacity to adapt and spread in many habitats (van Soest et al. 2012) contributing to organization and functioning at both community and ecosystem levels. These sessile metazoans provide an ecosystem configuration, interact with other organisms through a variety of trophic interactions (e.g. competition, deterrence and symbiosis) (Wulff 2006, 2012, Rützler 2012), and also play a role in large-scale processes such as nutrient cycling, primary production, calcification or bioerosion (Schlappy et al. 2010, Rützler 2012, Uriz et al. 2012), contributing to ecosystem functioning (Diaz and Rützler 2001, de Goeij et al. 2013).

\section{Sponge chemical ecology and microbial ecology}

One of the keys of the evolutionary success of this group lies in the close association between sponges and microbes, which dates back to the Precambrian era (Wilkinson 1984, Jackson et al. 2010, Uriz et al. 2012). The lack of motility of these invertebrates may induce a need to be defended, so several mechanisms including chemical defences emerged to increase their fitness (Taylor et al. 2007, Siegl et al. 2008). Some sponges may produce their own biologically active natural products against predators, competitors, or foulers, and others may benefit from the defensive properties of the metabolites produced by their microbes (Pawlik et al. 1995, Newbold et al. 1999, Amsler et al. 2000). Though chemical defences have been well studied in the phylum Porifera (Müller et al. 2004, Sipkema et al. 2005, Proksch et al. 2010), and it has been the preferred phylum of the marine natural product community over the last 50 years (Blunt et al. 2015), the origin of many compounds still remains controversial (König et al. 2006, Wang 2006, Hentschel et al. 2012).

Since many studies of sponge chemistry and microbiology have documented a huge chemical (Faulkner 2000, Moore 2006) and microbial diversity (Taylor et al. 2007, Webster et al. 2010, Lee et al. 2011) within these sessile invertebrates, the field of sponge symbiosis has rapidly expanded in the past years, fuelling research on chemical and microbial ecology. Today's major themes in sponge chemical ecology are to test the bioactivity of natural products regardless of the origin of these metabolites (Wright et al. 2011, Freeman and Gleason 2012, Nuñez-Pons et al. 2012) and to screen for new drugs with potential pharmacological and biotechnological applications (Leal et al. 2012a,b, Acevedo et al. 2013, Kampa et al. 2013). There are several papers about the variability of bioactive compounds at multiple temporal and spatial scales (Sacristán-Soriano et al. 2011a, 2012, Evans-Illidge et al. 2013) and many others that link host metabolites with symbionts from the sponge (Hochmuth et al. 2010, Penesyan et al. 2010, Indraningrat et al. 2016). Beneath these main themes, there are some papers dealing with sponge chemistry as a driver of community organization and structure (Paul et al. 2007, Pawlik et al. 2013) and a few papers focusing on trade-offs in defensive metabolite production (Ivanisevic et al. 2011, Gochfeld et al. 2012). Despite the increasing data on changing climate and other environmental stressors, very little research has addressed the effects of climate change on sponge chemistry (Duckworth et al. 2012) and the potential chemical shifts in response to infection, which are probably caused by abnormal environmental conditions (Webster et al. 2008). These topics clearly need scientific attention and it is likely that papers focusing on these issues will be available soon.

In sponge microbial ecology, several dozen papers also evidence the connection between associated microorganisms and natural products (König et al. 2006, Penesyan et al. 2009, Genta-Jouve and Thomas 2012). Other major themes addressed are the specificity or the ubiquity of the sponge microbiome (Erwin et al. 2012a, Alex et al. 2013, Webster et al. 2013b) and the sponge symbiotic metabolism (Hunting et al. 2010, Thomas et al. 2010a, Freeman et al. 2013). Additionally, there are number of papers on spatiotemporal dynamics of associated microbial communities assessing bacterial and also archaeal biodiversity (Sacristán-Soriano et al. 2011b, Bjork et al. 2013, Hardoim and Costa 2014). Some themes are receiving increasing attention from the scientific community due to the importance of the associated microbial community on sponge health, yet little research has focused attention on the resilience of sponge-microbe interactions to a changing climate or anthropogenic disturbances (Bell et al. 2013, Fan et al. 2013). Changes in environmental conditions might induce a number of sponge diseases if the host-symbiont partnership breaks down or deviates from normal functioning (Webster et al. 2008, Angermeier et al. 2012). Further, the era of 'omic' technologies in which we live 
will allow us to delve into evolutionary issues not only of sponge symbiosis (Thomas et al. 2010b, Fan et al. 2012) but also of sponge chemistry (Roper et al. 2009).

Can we go beyond highlighting topics that have received or require considerable attention to assess the impact of these topics on the scientific community? Who is interested in these topics? Only sponge lovers, or are they important outside the sponge research community? Do they contribute to general ecological and microbial theory, or what are the biotechnological implications? This mini-review analyses literature trends in sponge chemical and microbial ecology (i.e. papers on the interactions among sponge chemicals or sponge microbes and their environment) from the early stages of these research lines until 2014. Our goal is to help identify the audience and impact of these research lines, which can result in improved research questions, better journal selection and increased repercussion of these topics. Some book chapters and reviews published in the literature in the last four to five years exhaustively compile and analyse papers in both sponge ecology areas: chemistry (Proksch et al. 2010, Paul et al. 2011, Genta-Jouve and Thomas 2012) and microbiology (Hentschel et al. 2012, Schippers et al. 2012, Thacker and Freeman 2012). Consequently, rather than a traditional, narrative review of the literature, we took a quantitative approach based on a series of bibliometric indicators that offer an unbiased analysis of both sponge disciplines and highlight themes that will demand additional research in the near future.

\section{MATERIALS AND METHODS}

\section{Reference sampling and analysis}

Revising all chemical and microbial ecology literature on sponges can be a challenging task. Since the appearance of the Web of Knowledge (Thomson and Reuters 2014), investigating research trends is within our reach. Thanks to Garfield (Garfield 1964, 1970), the Web of Knowledge platform includes multidisciplinary resources for searching, tracking and measuring scientific literature and generating statistical reports. The Web of Science is one of the available tools that provides access to the world's leading citation databases. We used the Science Citation Index Expanded database to search and analyse the sponge chemical and microbial ecology. This database comprises over 8500 major journals across 150 disciplines and covers papers from 1900 to the present, making it a suitable dataset for achieving our goals. We also used the "Analyze" tool within this database to group published papers, analyse them and identify research trends.

For an evaluation of the literature on sponge chemical and microbial ecology we used the same criteria described by Becerro (2008). Specifically, we searched for i) (sponge OR porifera) AND chemi* AND ecolog* to target the sponge chemical ecology literature and ii) (sponge OR porifera) AND microb* AND ecolog* to target the sponge microbial ecology literature. This approximation was a way to objectify our search. The timespan used for these searches was from 1900 to 2014. The use of the asterisk allowed us to search for variants such as 'chemical or chemistry, microbial or microbe, and ecology, ecological or ecologically'. If any of the combinations of these variants appeared in the title, abstract or keywords, the target papers on sponge chemical and microbial ecology were selected. Our criterion of selection reflects our interest in those papers focusing on the interactions between sponge chemicals or sponge microbes and their environment. Thus, literature exclusively focused on sponge chemistry or microbiology was not considered. We reduced the false positives contrasting all the papers that resulted from our search against our selection criterion. We could not do so with the false negatives, so it is likely that some papers related to sponge chemical or microbial ecology were not selected because they did not include the terms (or any variants) used in our search in the title, abstract or keywords. To estimate the number of false negatives, we set a broader search on sponge ecology using the same terms used by Becerro (2008) (sponge OR porifera) AND ecolog* with an arbitrary timespan (1900 to 1990) that allowed us to check all the papers found. From this reference list, we found only one publication related to sponge chemical ecology that was missing with our original search strategy, suggesting a low number of false negatives. This reference was incorporated in the analysis. The papers analysed in this mini-review are exclusively those selected by our search strategy. The criteria used for our literature search are simple, unbiased, and easy to reproduce, as we verified several times (last time September 2015).

We used several indicators to compare the chemical and microbial literature. We recorded the total number of papers, the total number of citations, the average number of citations per publication (i.e. mean citation rate, MCR), the total number of citing papers and the h-index (Becerro 2008). The total number of papers reflects the productivity of the research area but shows no information on the impact of the studies. The total number of citations provides an idea of the importance of the research but may be biased by a few papers with an unusually high number of citations that inflate the impact of the remaining published works. The MCR is a measure of the relative importance of the research area but is biased by productivity. The total number of citing papers is the number of previous research studies related to the research area searched. The h-index, defined by Hirsch (2005) as the number of papers with a citation number $\geq h$, is a useful and unbiased indicator to estimate the importance of scientific outputs. Similar h-indexes imply similar importance of two research fields, while higher h values indicate greater importance regardless of the total number of papers or citations of the two scientific areas (Hirsch 2005). Although the hindex is widely accepted and has been proved useful by the scientific community, it seems to present a theoretical inconsistency in some cases (Waltman and van Eck 2012). The best approach to measuring the impact of scientific performance remains to be found (Ravallion and Wagstaff 2011, Waltman and van Eck 2013).

We wanted to complement the h-index with three other bibliometric indicators to estimate the overall and 
average scientific impact of two research fields. We calculated the highly cited papers (HCP) indicator, the aggregate of the natural logarithm of citations of each publication (AC), and the mean normalized citation score (MNCS) indicator. The HCP indicator, which behaves similarly to the h-index, counts the number of papers with at least a certain number of citations (Waltman and van Eck 2012, Schreiber 2013). To define that threshold we found it reasonable to use the MCR of both chemical and microbial datasets (Schreiber 2013), so papers with a citation number $\geq \mathrm{MCR}$ were taken as highly cited papers. The aggregate of the natural logarithm of citations of each publication is an indicator that describes a concave function of the number of citations of the publication dataset (Waltman and van Eck 2012). Like the h-index and HCP, such an indicator will typically be relatively insensitive to papers with a very large number of citations. The MNCS indicator measures the average impact of a publication dataset but, unlike MCR, it normalizes for differences in citation window length. A MNCS value above (below) one means that on average the papers of the dataset are cited more (less) frequently than would be expected based on their publication year (Waltman and van Eck 2013).

The Science Citation Index Expanded database provides results as a function of Authors, Subject Categories and Journals, which allows quantitative examination of the research output by contributing researchers, disciplines and scientific journals. Subject categories are non-exclusive, so a single paper may be included in several disciplines. Consequently, by adding up the number of papers or percentages for each category, we obtain a number larger than the actual number of records found or percentages larger than $100 \%$. For details on what is comprised in each subject category, see the webpage (Scope Notes, Science Citation Index Expanded). From the Web of Knowledge (Thomson and Reuters 2014), we can also have access to the Journal
Citation Reports, which rank the journals from specific subject categories based on the journal impact factor.

\section{RESULTS}

\section{Impact of sponge chemical and microbial ecology}

A total of 312 papers initially met the sponge chemical ecology requirements, while 190 papers were found with the microbial ecology search. After checking all published works, 82 papers of the chemical search and 59 papers of the microbial output were completely unrelated to our goal and did not meet our definition of sponge chemical and microbial ecology so, they were discarded. We found an additional publication (Green 1977) with a broad search that also met the chemical ecology criterion and was subsequently added to the sponge chemical output (see Reference sampling above). Thus, a total of 231 and 131 papers of chemical and microbial ecology, respectively, were analysed. The chemical output accounted for 6997 citations while microbial papers totalled 4408 citations, which showed an increasing trend over the years but with a marked rise in the early 1990s in both cases when the number of papers started growing (Fig. 1). In the chemical ecology area, the number of papers showed a low increase in the early 1990s, with about 4 papers per year. Then, the rate doubled between the late 1990s and the early 2000 s, and has increased to an average of 14 papers in the last 10 years (Fig. 1A). In the microbial ecology field, the number of papers exhibited an irregular increase, with several 'blank' periods of no publication records and isolated published works. Then, the rate increased at 2 papers per year between the late 1990s and the early 2000s, and has increased to an average of almost 12 papers in the last 10 years (Fig. 1B).

Sponge chemical ecology ranked first in terms of productivity (i.e. number of papers), almost doubling the number of papers published in microbial ecology

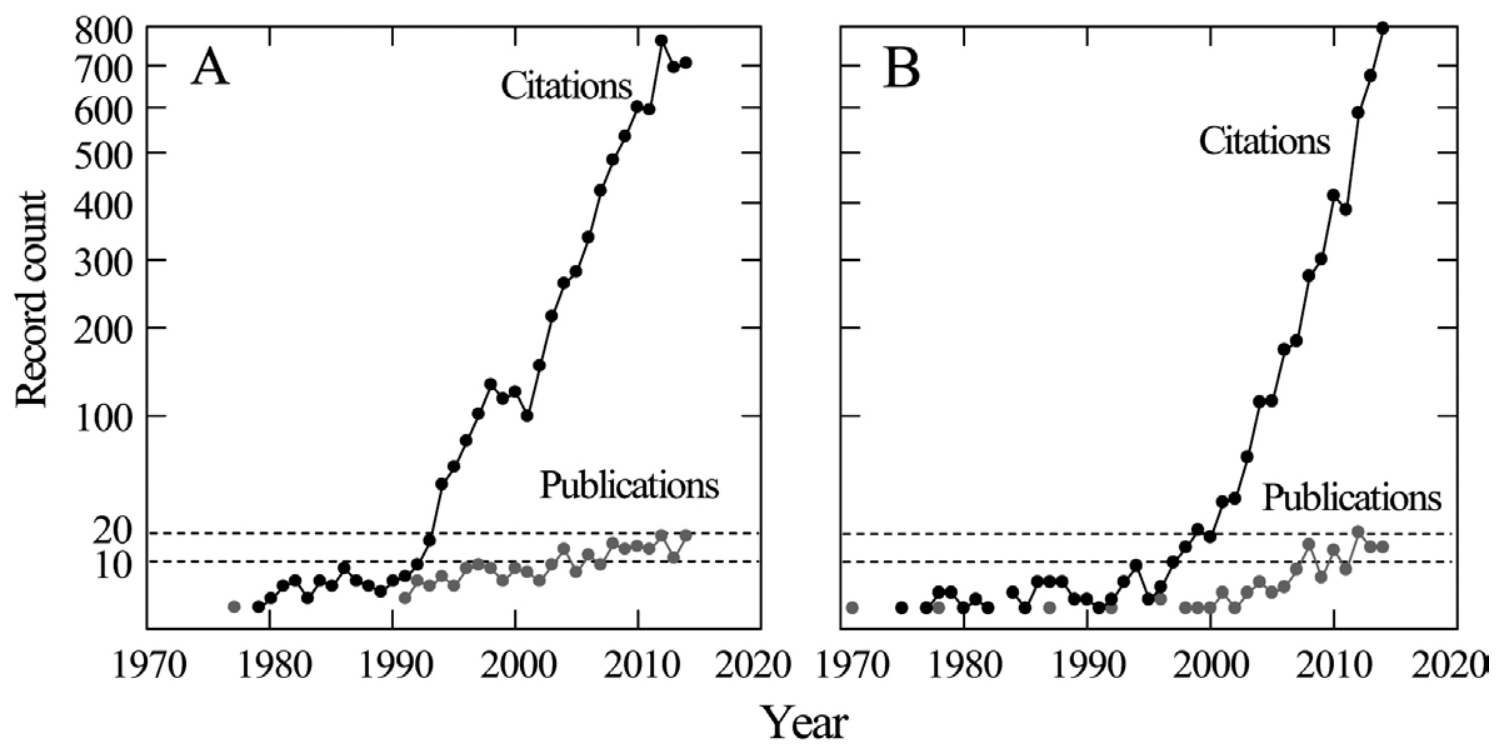

Fig. 1. - Evolution of the number of papers (in grey) and citations (in black) on sponge chemical (A) and microbial (B) ecology found in the Science Citation Index Expanded database from 1900 to 2014. Search terms: (sponge OR porifera) AND chemi* AND ecolog* and (sponge OR porifera) AND microb* AND ecolog*, respectively. 
Table 1. - Total number of papers (n), total number of citations (cites), mean citation rate (MCR), total number of citing articles (art), hindex, highly cited papers indicator (HCP), aggregate of the natural logarithm of citations of each publication (AC), and mean normalized citation score indicator (MNCS) for both sponge research areas searched in the Science Citation Index Expanded database from 1900 to 2014. Research output shown by research area and within each area categorized by publication type (articles and reviews).

\begin{tabular}{|c|c|c|c|c|c|c|c|c|}
\hline Sponge research area & $\mathrm{n}$ & cites & MCR & art & $\mathrm{h}$ & $\mathrm{HCP}$ & $\mathrm{AC}^{\mathrm{a}}$ & $\mathrm{MNCS}^{\mathrm{b}}$ \\
\hline Chemical ecology & 231 & 6997 & 30.29 & 4099 & 44 & 71 & 631.43 & 3.13 \\
\hline Articles & 184 & 4187 & 22.76 & - & 36 & 66 & 478.73 & 2.28 \\
\hline Reviews & 43 & 2807 & 65.28 & - & 24 & 12 & 148.04 & 8.35 \\
\hline Microbial ecology & 131 & 4408 & 33.65 & 2498 & 35 & 36 & 348.84 & 2.25 \\
\hline Articles & 103 & 2927 & 28.42 & - & 29 & 30 & 263.17 & 2.06 \\
\hline Reviews & 26 & 1442 & 55.46 & - & 14 & 8 & 79.73 & 3.61 \\
\hline
\end{tabular}

a, $\mathrm{AC}=\sum_{i=1}^{\mathrm{n}} \ln \left(\mathrm{c}_{i}+1\right) ;{ }^{\mathrm{b}}, \mathrm{MNCS}=\frac{1}{\mathrm{n}}\left(\frac{\mathrm{c}_{1}}{\mathrm{e}_{1}}+\ldots+\frac{\mathrm{c}_{\mathrm{n}}}{\mathrm{e}_{\mathrm{n}}}\right)$, where $\mathrm{n}$ denotes the number of papers of the research field, $\mathrm{c}_{i}$ denotes the number of citations of the $i$ th publication, and $\mathrm{e}_{i}$ denotes the average number of citations of all papers in the year in which the $i$ th publication appeared.

Table 2. - Number of papers (n), percentage of total papers on sponge chemical and microbial ecology (\%), and h-index for each subject category. Ranking for each subject category within brackets; '-' no records found.

\begin{tabular}{|c|c|c|c|c|c|c|}
\hline \multirow{2}{*}{ Subject category } & \multicolumn{3}{|c|}{ Chemical ecology } & \multicolumn{3}{|c|}{ Microbial ecology } \\
\hline & $\mathrm{n}$ & $\%$ & $\mathrm{~h}$ & $\mathrm{n}$ & $\%$ & $\mathrm{~h}$ \\
\hline Marine and Freshwater Biology & 87 & $37.7(1)$ & 28 & 41 & $31.3(2)$ & 16 \\
\hline Ecology & 64 & $27.7(2)$ & 24 & 29 & $22.1(3)$ & 13 \\
\hline Biochemistry and Molecular Biology & 35 & $15.2(3)$ & 19 & 4 & $3.1(9)$ & 4 \\
\hline Chemistry, Medicinal & 29 & $12.6(4)$ & 15 & 10 & $7.6(6)$ & 5 \\
\hline Oceanography & 26 & $11.3(5)$ & 14 & 14 & $10.7(5)$ & 9 \\
\hline Multidisciplinary Sciences & 19 & $8.2(6)$ & 8 & 16 & $12.2(4)$ & 7 \\
\hline Pharmacology and Pharmacy & 15 & $6.5(7)$ & 11 & 4 & $3.1(10)$ & 4 \\
\hline Microbiology & 14 & $6.1(8)$ & 11 & 45 & $34.4(1)$ & 21 \\
\hline Biotechnology and Applied Microbiology & 13 & $5.6(9)$ & 9 & 8 & $6.1(7)$ & 6 \\
\hline Chemistry, Organic & 13 & $5.6(10)$ & 10 & - & - & - \\
\hline Plant Sciences & 12 & $5.2(11)$ & 8 & 3 & $2.3(12)$ & 3 \\
\hline Zoology & 12 & $5.2(12)$ & 9 & - & - & - \\
\hline Environmental Sciences & 11 & $4.8(13)$ & 9 & 7 & $5.3(8)$ & 7 \\
\hline Chemistry, Multidisciplinary & 8 & $3.5(14)$ & 6 & - & - & - \\
\hline Biology & 6 & $2.6(15)$ & 6 & 1 & $0.8(15)$ & 1 \\
\hline Geosciences, Multidisciplinary & 6 & $2.6(16)$ & 4 & 2 & $1.5(13)$ & 2 \\
\hline Evolutionary Biology & 5 & $2.5(17)$ & 5 & - & - & - \\
\hline Geography, Physical & 4 & $1.7(18)$ & 3 & 1 & $0.8(16)$ & 1 \\
\hline Fisheries & 3 & $1.3(19)$ & 3 & 2 & $1.5(14)$ & 1 \\
\hline Biodiversity and Conservation & 3 & $1.3(20)$ & 2 & 1 & $0.8(17)$ & 1 \\
\hline Limnology & 2 & $0.9(21)$ & 2 & 4 & $3.1(11)$ & 3 \\
\hline Mycology & 2 & $0.9(22)$ & 2 & 1 & $0.8(18)$ & 1 \\
\hline Toxicology & 2 & $0.9(23)$ & 2 & - & - & - \\
\hline Economics & 1 & $0.4(24)$ & 1 & 1 & $0.8(19)$ & 1 \\
\hline Environmental Studies & 1 & $0.4(25)$ & 1 & 1 & $0.8(20)$ & 1 \\
\hline Genetics and Heredity & 1 & $0.4(26)$ & 1 & - & - & - \\
\hline Physiology & 1 & $0.4(27)$ & 1 & - & - & - \\
\hline Behavioural Sciences & 1 & $0.4(28)$ & 1 & - & - & - \\
\hline Engineering, Multidisciplinary & 1 & $0.4(29)$ & 0 & 1 & $0.8(21)$ & 0 \\
\hline Chemistry, Physical & 1 & $0.4(30)$ & 0 & - & - & - \\
\hline Materials Science, Multidisciplinary & 1 & $0.4(31)$ & 0 & - & - & - \\
\hline Geology & - & - & - & 1 & $0.8(22)$ & 1 \\
\hline Palaeontology & - & - & - & 1 & $0.8(23)$ & 1 \\
\hline Integrative and Complementary Medicine & - & - & - & 1 & $0.8(24)$ & 1 \\
\hline Veterinary Sciences & - & - & - & 1 & $0.8(25)$ & 1 \\
\hline Medicine Research Experimental & - & - & - & 1 & $0.8(26)$ & 1 \\
\hline
\end{tabular}

(Table 1). Chemical ecology also ranked first in the total number of citations received and had been cited by more papers, but the MCR was similar to that of microbial ecology (Table 1). The highest h-index obtained by chemical ecology reflected a greater overall impact on the scientific community than those of microbial ecology. The HCP and AC indicators supported a greater importance of the sponge chemical ecology dataset (Table 1). However, if we assessed the average influence of both publication records, we detected that on average the papers of both disciplines were cited equally and more frequently than would be expected (MNCS $>1$; Table 1).

Of the 231 papers in the chemical ecology field, 43 were reviews $(18.6 \%)$. Almost the same percentage of reviews occurred in microbial ecology (19.8\%). These reviews accounted for over $32 \%$ of the citations in both research areas (Table 1). Compared with regular articles, these reviews exhibited a twofold to threefold increase in the MCR. However, normalizing for differences in window citation length reduced those differences in microbial ecology (i.e. similar MNCS values) but did not do so in chemical ecology, where reviews were cited much more frequently (i.e. high MNCS value) (Table 1). When the overall impact was assessed, the greatest aggregate importance lay in regular articles, which showed higher values in the h-index, HCP and AC indicators (Table 1).

According to our search and our selection criterion, the 231 papers on chemical ecology were contributed 
by 718 authors. Almost $20 \%$ of the researchers (129) had multiple contributions (two or more papers) and only $3.2 \%$ published five or more papers. The 131 papers on sponge microbial ecology were contributed by 445 researchers, $19 \%$ of them had multiple contributions, and just $1.6 \%$ had five or more papers.

Papers on sponge chemical and microbial ecology covered over 20 subject categories in the Web of Knowledge (31 and 26, respectively; Table 2). To estimate the overall impact of papers from each subject category, we only showed the h-index because we reached similar conclusions with other indicators. In the chemical ecology field, about $40 \%$ of the 231 papers belonged to the Marine and Freshwater Biology category, followed by almost $30 \%$ of the records that belonged to the Ecology category. Both categories showed a greater overall impact on the research community (i.e. an h-index of 28 and 24, respectively). In the microbial ecology field, over $30 \%$ of the 131 papers belonged to the Microbiology and Marine and Freshwater Biology categories. Microbiology ranked first in overall importance (i.e. an h-index of 21), while Ecology was represented by over $20 \%$ of the papers (Table 2).

Over 4000 papers representing 107 subject categories cited the 231 papers on sponge chemical ecology, whereas the 131 records published on microbial ecology were cited by almost 2500 papers that represented 100 categories. This large number of subject categories compared with the relatively low number of categories that represented the chemical and microbial research output (i.e. around 29) implies a great interest in sponge chemical and microbial ecology not only among the scientific community in the same research area but also in other scientific disciplines. Considering those categories, which represented over $10 \%$ of papers on chemical ecology and papers that cited them, a goodness of fit (Sokal and Rohlf 1995) showed no significant differences in the proportion of papers in specific subject categories $(\mathrm{G}=4.197, \mathrm{df}=4, \mathrm{P}=0.380)$. Similarly, subject categories published an equal proportion of papers on microbial ecology and those that cited them $(\mathrm{G}=15.447, \mathrm{df}=8, \mathrm{P}=0.051)$. Although the proportion of papers in most of the categories was similar in sponge chemical ecology and microbial ecology, there was some degree of variability. In the first research field, the proportion of papers published was slightly greater in the Multidisciplinary Sciences category, while the papers cited showed a greater percentage in the categories Biotechnology and Applied Microbiology and Fisheries (Fig. 2A). In the second research area, the proportion of papers published exhibited a twofold increase compared with those cited in Multidisciplinary Sciences and Limnology (Fig. 2B). The proportion of papers cited approximately doubled the proportion of papers published in Biotechnology and Applied Microbiology, Palaeontology, and Geosciences Multidisciplinary, and was over $200 \%$ higher in Biochemistry and Molecular Biology and Biology (Fig. 2B).

The Marine and Freshwater Biology and Ecology subject categories comprised the majority of papers on

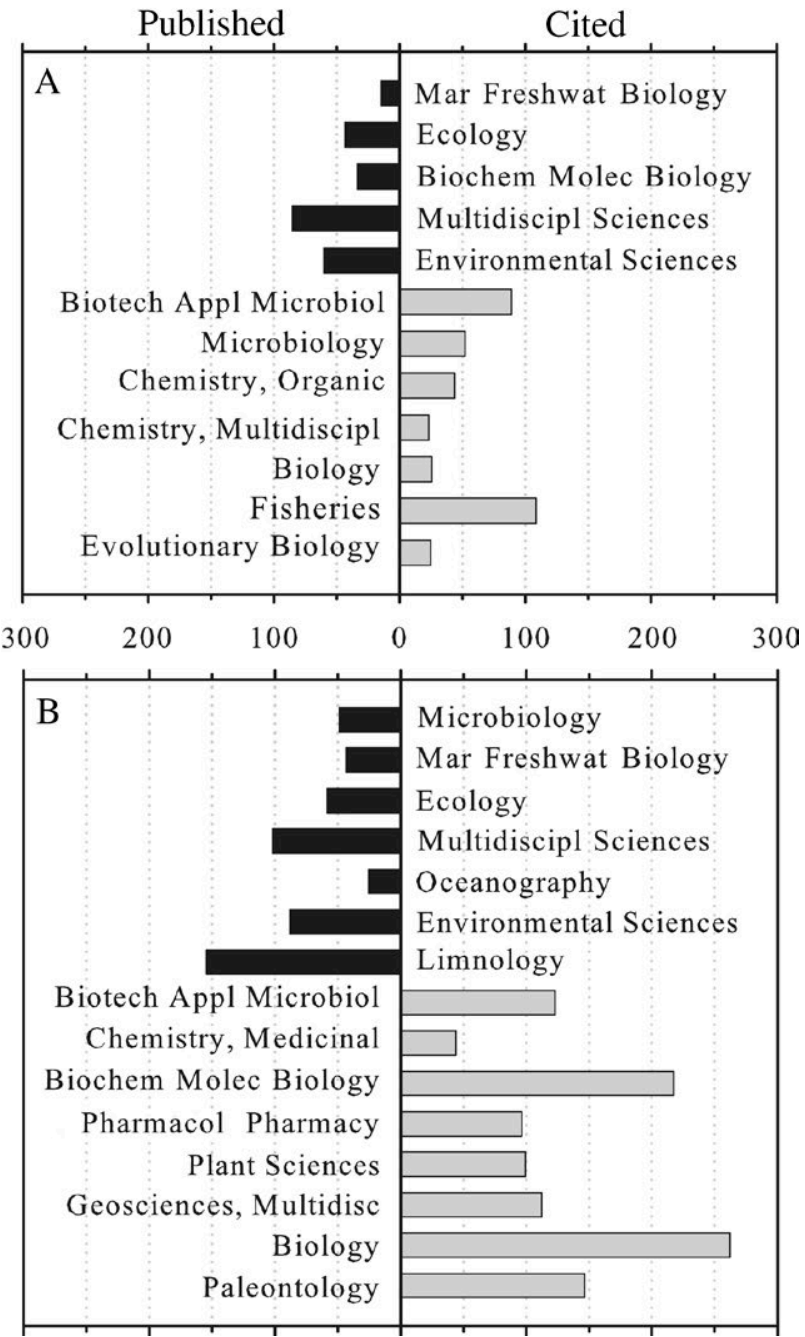

Fig. 2. - Increasing rate (\%) of papers on chemical (A) and microbial (B) ecology published ([published - cited] / cited; in black) or cited ([cited - published] / published; in grey) within several subject categories found in the Science Citation Index Expanded database. Subject categories were ordered within published or cited papers as a function of the percentage of the total papers represented by each category in descending order. The remaining categories were excluded either because the proportions of papers published or cited were equivalent (i.e. the relative value did not deviate from 1) or because the percentage of the total papers in a subject category was below 1\%. Black bars show a higher proportion of chemical and microbial ecology papers published than cited, whereas the opposite is true for grey bars. Mar Freshwat Biology, Marine and Freshwater Biology; Biochem Molec Biology, Biochemistry and Molecular Biology; Multidiscipl Sciences, Multidisciplinary Sciences; Biotech Appl Microbiol, Biotechnology and Applied Microbiology; Chemistry, Multidiscipl, Chemistry, Multidisciplinary; Pharmacol Pharmacy, Pharmacology and Pharmacy; Geosciences, Multidisc, Geosciences, Multidisciplinary.

sponge chemical ecology (122 of 231), whereas the $M i$ crobiology subject category, jointly with the two previous categories, accumulated over $60 \%$ of the papers on sponge microbial ecology (84 of 131). The Journal Citation Reports showed 236 and 352 journals belonging to those categories, respectively. These journals were ranked by descending impact factor (IF) and classified into four groups or quartiles. The first two quartiles covered the high impact factor journals. The first quartile covered the journals with an IF above 2.73 or 3.05 , including journals from the Microbiology subject cat- 

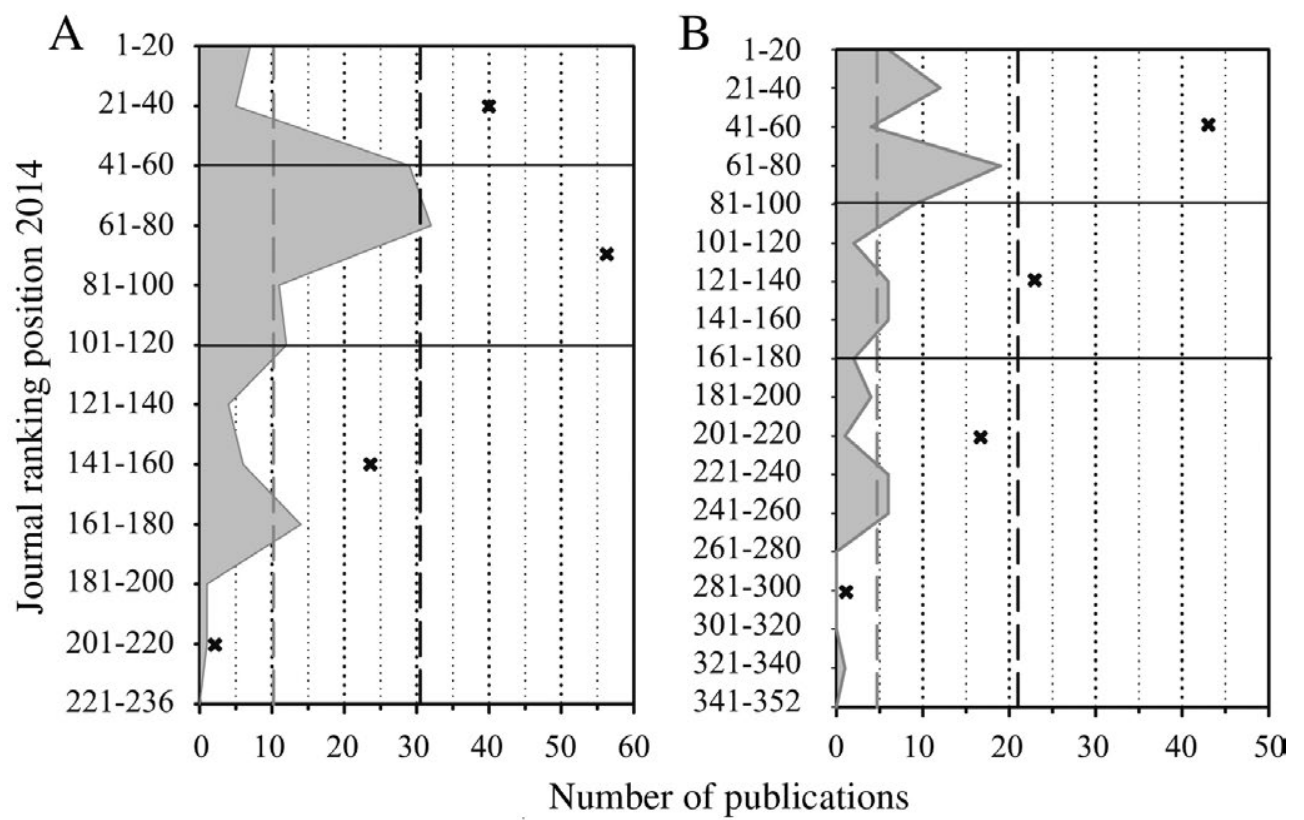

Fig. 3. - Distribution of the papers on sponge chemical (122; A) and microbial (84; B) ecology included in the subject categories Marine and Freshwater Biology, Ecology and Microbiology (only for sponge microbial ecology) as a function of the impact factor of the journals. The journals are ranked with descending impact factor ( 1 is the highest impact factor) and grouped in categories of 20 journals (16 and 12 in the bottom groups, respectively). Horizontal lines represent the first and the second quartile (i.e. the upper and the lower lines, respectively) of journals. Dashed grey line denotes the number of papers expected per category of 20 journals under the assumption of equal probability of publishing the 122 and 84 papers in any journal category. Dashed black line represents the number of papers expected per quartile under the assumption of equal probability of publishing in any of the four quartiles. Crosses are the number of papers in each quartile.

Table 3. - Number of papers (n), percentage of total papers on sponge chemical and microbial ecology (231 and 131, respectively; \%), and cumulative percentage (cum) in the top 10 journals publishing on these research areas according to the Web of Knowledge (Thomson and Reuters 2014); * Journals that do not belong to the Marine and Freshwater Biology, Ecology and Microbiology subject categories.

\begin{tabular}{|c|c|c|c|}
\hline Journal & $\mathrm{n}$ & $\%$ & cum \\
\hline \multicolumn{4}{|l|}{ Chemical ecology } \\
\hline Marine Ecology Progress Series & 16 & 6.9 & 6.9 \\
\hline Journal of Chemical Ecology & 15 & 6.5 & 13.4 \\
\hline Marine Biology & 14 & 6.1 & 19.5 \\
\hline Marine Drugs* & 9 & 3.9 & 23.4 \\
\hline$P \operatorname{LoS} O N E^{*}$ & 8 & 3.5 & 26.8 \\
\hline Journal of Experimental Marine Biology and Ecology & 7 & 3.0 & 29.9 \\
\hline Marine Ecology-an Evolutionary Perspective & 6 & 2.6 & 32.5 \\
\hline Natural Product Reports* & 6 & 2.6 & 35.1 \\
\hline Biofouling & 5 & 2.2 & 37.2 \\
\hline Hydrobiologia & 5 & 2.2 & 39.4 \\
\hline \multicolumn{4}{|l|}{ Microbial ecology } \\
\hline FEMS Microbiology Ecology & 10 & 7.6 & 7.6 \\
\hline Environmental Microbiology & 8 & 6.1 & 13.7 \\
\hline PLoS ONE* & 7 & 5.3 & 19.1 \\
\hline Microbial Ecology & 6 & 4.6 & 23.7 \\
\hline Marine Biology & 5 & 3.8 & 27.5 \\
\hline Marine Ecology Progress Series & 5 & 3.8 & 31.3 \\
\hline Advances in Marine Biology & 4 & 3.1 & 34.4 \\
\hline ISME Journal & 4 & 3.1 & 37.4 \\
\hline PNAS* & 4 & 3.1 & 40.5 \\
\hline Marine Drugs* & 4 & 3.1 & 43.5 \\
\hline
\end{tabular}

egory, while journals belonging to the second quartile had an IF greater than 1.64 or 1.94 , respectively. The third and fourth quartiles included the low impact factor journals (below those IF). We used a goodness of fit statistic to measure whether the 122 and 84 papers on sponge chemical and microbial ecology in these subject categories deviated from what was expected under the assumption of equal probability to publish in any journal. Journals from the first and the second quartiles published significantly more papers on sponge chemical and microbial ecology than journals with lower impact factors $(\mathrm{G}=59.059$, $\mathrm{df}=3, \mathrm{P}<0.001 ; \mathrm{G}=63.704$, $\mathrm{df}=3, \mathrm{P}<0.001$; respectively, Fig. 3). However, there was a contrasting pattern between the two research areas. The top 20 journals that belonged to Marine and Freshwater Biology and Ecology were more deficient in papers about sponge chemical ecology than expected, while they published more papers on sponge microbial ecology than expected, including the top journals from the Microbiology category (Fig. 3).

Overall, the 231 and 131 papers on sponge chemical and microbial ecology were published in 103 and 69 journals, respectively. Most of them have published one single paper on either of the two research areas 
and the top 10 journals account for around $40 \%$ of all papers in both disciplines (Table 3). The majority of those journals belonged to the Marine and Freshwater Biology, Ecology and Microbiology subject categories and only four did not (Table 3). Four of the top 10 journals that published papers in sponge chemical ecology focused on marine biology and ecology, three on chemical ecology/natural products, and one on aquatic biology, biological interactions and general science. Three of the top 10 journals that published papers in sponge microbial ecology focused on marine biology and ecology, four on microbial ecology, two on general science, and one on natural products (Table 3 ).

\section{DISCUSSION}

\section{Sponge chemical and microbial ecology: past, present and future}

We looked at the impact of sponge chemical and microbial ecology on the scientific community. To do so, we quantitatively analysed references published on these research areas gathered within the Science Citation Index Expanded database. This quantitative analysis provides a historical view of these two disciplines over the years, a current diagnose of their status, and opportunities to take full advantage of the existing literature and to improve future research on these topics.

According to our search history and selection criterion, literature on sponge chemical and microbial ecology appeared during the 1970s. Despite the simultaneous appearance of both sponge research areas, chemical ecology started growing a little bit earlier and has shown a gradual increase since the 1990s; its overall impact, evaluated by a variety of bibliometric indicators, seems to be greater than those of microbial ecology. However, the average impact of papers from both disciplines evaluated by the MNCS indicator is quite similar. Although the h-index seems to show some theoretical inconsistency (Waltman and van Eck 2012), we obtained the same results with other available bibliometric indicators. For this empirical application at least, the h-index rankings of overall influence are reliable. The low number of papers of sponge microbial ecology may be a consequence of the low number of contributors to this particular research field. A huge majority of $81 \%$ of the researchers had only one paper, while almost $2 \%$ had more than five papers. However, percentages were similar in the chemical ecology area, in which $82 \%$ of the researchers had a single paper and around $3 \%$ had five or more. These results suggest that sponge chemical and microbial ecologies are steadily growing disciplines that will likely be developing in the near future.

Reviews are crucial and useful tools for collecting information and updating the status of a particular research field. Around $20 \%$ of the papers on sponge chemical and microbial ecology were reviews, which is about twice the percentage of reviews in the broader field of sponge ecology (9.8\%, updated to 2014 from (Becerro 2008)). Though the reviews showed higher average importance in chemical and microbial ecology research, the aggregate impact of this publication type was small compared with that of regular articles, which showed higher values of three different bibliometric indicators. Two reasons may be behind these unexpected results. First, an overproduction of reviews in sponge chemical and microbial ecology research may reduce their relative impact on the scientific community. For example, two excellent reviews of the biotechnological potential of marine surface-associated microbial communities that addressed the same research topic were published in the space of 2 years (Egan et al. 2008, Penesyan et al. 2010). Second, a lack of empirical data in both fields which may make regular papers more valuable and in higher demand than review papers.

A huge impact on the scientific community is derived from the large number of subject categories that cited papers on sponge chemical and microbial ecology. Chemical ecology research on sponges is highly cited by the categories Biotechnology and Applied Microbiology and Fisheries compared with the percentage of papers on chemical ecology published in those same categories. Sponge microbial ecology, however, is extensively cited by the categories Biotechnology and Applied Microbiology, Biochemistry and Molecular Biology, Biology and Palaeontology. The demand for information on chemical and microbial ecology essentially comes from applied disciplines. Since many microbial symbionts were found to produce bioactive compounds that can be used for their biotechnological potential, microbe-sponge interactions have attracted increasing attention from applied research (Wang 2006, Dunlap et al. 2007, Egan et al. 2008), and the ecological perspectives of these associations have even become essential to gain an understanding of how those bioactive metabolites are produced (Taylor et al. 2007). Hence, applied microbiology (i.e. organism manipulation to make products or solve problems to meet human needs) fuels part of its research by citing papers on sponge chemical and microbial ecology. Similarly, applied chemistry (i.e. drug discovery and pharmacognosy) does so by citing research on the same research fields.

Surprisingly, there is a lower number of citations than expected from the subject categories Marine and Freshwater Biology, Ecology and Microbiology, which accounted for the highest number of papers on chemical and microbial ecology. This finding suggests that the ecological perspectives of sponge chemistry and microbiology may fall outside the interests of many researchers who publish in those same categories. Perhaps many studies on sponge chemical and microbial ecology focus their attention at the species level, so their impact on the ecological community decreases, as suggested by Becerro (2008).

Further evidence suggests that sponge chemical ecology contributes little to the broader field of ecology. Although the journals from the Marine and Freshwater Biology and Ecology categories published more papers on sponge chemical ecology that fall above the average impact factor for these categories than expected in the first two quartiles, the top 20 journals published only 7 out of 122 papers focusing on this scientific field. This 
represented around 3\% fewer papers than expected under the assumption of equal probability of publishing the 122 papers in any of the delimited groups of 20 journals. This finding may imply that, despite the great quality of research in sponge chemical ecology, the general approach taken by chemical ecologists probably falls outside the scope of the top journals. This opens up a number of possibilities for approaching chemical ecology research with a broader ecological scope. Contrastingly, sponge microbial ecology seems to make a greater contribution to broader ecological issues. The first quartile of journals that belonged to the Marine and Freshwater Biology, Ecology and Microbiology categories published over $50 \%$ of the papers on sponge microbial ecology. Moreover, the number of papers in the top 20 journals is $1.5 \%$ higher than expected, which may reveal the high quality of the research and the interest of the top journals in this research.

Sponges are considered an ecologically important group in marine benthic communities (McClintock et al. 2005, Downey et al. 2012), as evidenced in our search record. The vast majority of studies in chemical ecology deal with the biological activity of natural products from sponges (Wright et al. 2011, Freeman and Gleason 2012, Nuñez-Pons et al. 2012) and their biotechnological potential (Leal et al. 2012a, b, Acevedo et al. 2013, Kampa et al. 2013). However, sponges harbour complex microbial communities that must be taken into consideration in the ecology research field. In fact, several dozen papers have already assessed the specificity of these sponge-associated communities (e.g. Erwin et al. 2012a, Alex et al. 2013, Webster et al. 2013b), while others have shown that some symbiotic microorganisms can play a role as producers of biologically active compounds (Penesyan et al. 2009, Genta-Jouve and Thomas 2012, Indaningrat et al. 2016). In addition, there is another aspect that must be taken into account when assessing symbiont diversity and variability: different methods might influence the microbial community recovered, as shown by Hardoim et al. (2014). Furthermore, the sponge microbiome possesses a huge diversity of metabolisms that may be involved in ecosystem processes and functioning (e.g. nutrient cycling), as described in many papers (e.g. Grozdanov and Hentschel 2007, Erwin and Thacker 2008, Freeman et al. 2013). Such important functions of the sponge holobiont (i.e. host plus symbionts) may modulate the organization and functioning of marine benthic communities (Hill 1996, Jimenez and Ribes 2007, Paul et al. 2007). Although much of our knowledge on sponge chemistry and associated microbiota is based on a static picture, few studies have documented spatiotemporal dynamics of both bioactive compounds (Sacristán-Soriano et al. 2011a, 2012, Evans-Illidge et al. 2013) and symbionts of the host (Sacristán-Soriano et al. 2011b, Erwin et al. 2012b, Bjork et al. 2013). As a result, these research lines will further enhance our understanding of the sponge holobiont and will help define a threshold of natural variation. We might then be able to distinguish between natural shifts, including allocation trade-offs of chemical defences (Ivanisevic et al. 2011, Gochfeld et al. 2012), and abnormal changes due to environmental/anthropogenic factors. We are just starting to understand the importance of microbial symbionts on sponge health. We are yet to make significant progress in topics such as sponge disease and assessing the sensitivity of sponge symbioses (Bell et al. 2013, Fan et al. 2013) and chemical profiles (Duckworth et al. 2012) to environmental stressors such as climate change. A breakdown in host-symbiont partnerships or the alteration of the sponge chemistry as a result of global warming or anthropogenic disturbances may profoundly affect the ability of sponges to protect themselves from predation, fouling, or infections (Webster et al. 2008, Angermeier et al. 2012). In a period in which rapid environmental changes and degradation of marine habitats are evidenced, these themes should lead research in chemical and microbial ecology. Further, the advances in 'omic' technologies will allow us to delve into evolutionary issues of sponge symbiosis such as the mechanism that sponges may use to discriminate between food bacteria and symbionts (Thomas et al. 2010b), to provide insights into symbiont functions (Fan et al. 2012), and to increase our understanding of the evolution of sponge chemistry (Roper et al. 2009).

Overall, chemical and microbial ecology in sponges are disciplines that share many areas, both contributing to our understanding of host-symbiont interactions, areas that have proved useful for applied sciences. However, an extra effort is needed to make progress on fundamental ecological issues such as the role of sponge symbioses in population dynamics and community organization (Bell et al. 2013, Webster et al. 2013a). This mini-review also highlights some research topics, including climate change, disease, and evolutionary and functional issues that we believe deserve further attention and will increase awareness and importance of chemical and microbial ecology within the broader field of ecology. They will also contribute empirical data that may help reinforce the urgent need to preserve our marine ecosystems.

\section{ACKNOWLEDGEMENTS}

We thank N. Webster and D. Sipkema for their comments and suggestions on a previous version of the manuscript. We also thank the anonymous reviewer for his/her valuable remarks. This research is part of the PhD thesis of OSS, who was supported by a CSIC pre-doctoral grant. The research was funded by the Spanish government (SOLID: CTM2010-17755 and BENTHOMICS: CTM2010-22218) and is a contribution of the Consolidated Research Group "Grupo de Ecología Bentónica" (SGR2009-655) of the Catalan Government.

\section{REFERENCES}

Acevedo M.S., Puentes C., Carreno K., et al. 2013. Antifouling paints based on marine natural products from Colombian Caribbean. Int. Biodeterior. Biodegrad. 83: 97-104.

http://dx.doi.org/10.1016/j.ibiod.2013.05.002

Alex A., Silva V., Vasconcelos V., et al. 2013. Evidence of unique 
and generalist microbes in distantly related sympatric intertidal marine sponges (Porifera: Demospongiae). PLoS ONE 8: e80653.

http://dx.doi.org/10.1371/journal.pone.0080653

Amsler C.D., Moeller C.B., McClintock J.B., et al. 2000. Chemical defenses against diatom fouling in Antarctic marine sponges. Biofouling 16: 29-45

http://dx.doi.org/10.1080/08927010009378428

Angermeier H., Glockner V., Pawlik J.R., et al. 2012. Sponge white patch disease affecting the Caribbean sponge Amphimedon compressa. Dis. Aquat. Org. 99: 95-102. http://dx. doi.org/10.3354/dao02460

Becerro M.A. 2008. Quantitative trends in sponge ecology research. Mar. Ecol. Evol. Persp. 29: 167-177. http://dx.doi.org/10.1111/j.1439-0485.2008.00234.x

Bell J.J., Davy S.K., Jones T., et al. 2013. Could some coral reefs become sponge reefs as our climate changes? Global Change Biol. 19: 2613-2624. http://dx.doi.org/10.1111/gcb.12212

Bergquist P.R. 1978. Sponges. Univ. California Press, Berkeley, CA, USA

Bjork J.R., Diez-Vives C., Coma R., et al. 2013. Specificity and temporal dynamics of complex bacteria-sponge symbiotic interactions. Ecology 94: 2781-2791. http://dx doi.org/10.1890/13-0557.1

Blunt J.W., Copp B.R., Keyzers R.A., et al. 2015. Marine natural products. Nat. Prod. Rep. 32: 116-211. http://dx.doi.org/10.1039/C4NP00144C

Boury-Esnault N., Rützler K. (eds). 1997. Thesaurus of sponge morphology. Smithson. Contrib. Zool. 596: 1-55.

Carrera M.G., Botting J.R. 2008. Evolutionary history of Cambrian spiculate sponges: Implications for the Cambrian evolutionary fauna. Palaios 23: 124-138 http://dx.doi.org/10.2110/palo.2006.p06-089r

de Goeij J.M., van Oevelen D., Vermeij M.J.A., et al. 2013. Surviving in a marine desert: the sponge loop retains resources within coral reefs. Science 342: 108-110. http://dx.doi.org/10.1126/science.1241981

Diaz M.C., Rützler K. 2001. Sponges: An essential component of Caribbean coral reefs. Bull. Mar. Sci. 69: 535-546.

Downey R.V., Griffiths H.J., Linse K., et al. 2012. Diversity and distribution patterns in high Southern latitude sponges. PLoS ONE 7: e41672. http://dx.doi.org/10.1371/journal.pone.0041672

Duckworth A.R., West L., Vansach T., et al. 2012. Effects of water temperature and $\mathrm{pH}$ on growth and metabolite biosynthesis of coral reef sponges. Mar. Ecol. Prog. Ser. 462: 67-77. http://dx.doi.org/10.3354/meps09853

Dunlap W.C., Battershill C.N., Liptrot C.H., et al. 2007. Biomedicinals from the phytosymbionts of marine invertebrates: A molecular approach. Methods 42: 358-376. http://dx.doi.org/10.1016/j.ymeth.2007.03.00

Egan S., Thomas T., Kjelleberg S. 2008. Unlocking the diversity and biotechnological potential of marine surface associated microbial communities. Curr. Opin. Microbiol. 11: 219-225. http://dx.doi.org/10.1016/j.mib.2008.04.001

Erwin P.M., Thacker R.W. 2008. Phototrophic nutrition and symbiont diversity of two Caribbean sponge-cyanobacteria symbioses. Mar. Ecol. Prog. Ser. 362: 139-147. http://dx.doi.org/10.3354/meps07464

Erwin P.M., López-Legentil S., Gonzalez-Pech R., et al. 2012a. A specific mix of generalists: bacterial symbionts in Mediterranean Ircinia spp. FEMS Microbiol. Ecol. 79: 619-637. http://dx.doi.org/10.1111/j.1574-6941.2011.01243.x

Erwin P.M., Pita L., López-Legentil S., et al. 2012b. Stability of sponge-associated bacteria over large seasonal shifts in temperature and irradiance. Appl. Environ. Microbiol. 78: 7358-7368. http://dx.doi.org/10.1128/AEM.02035-12

Evans-Illidge E.A., Logan M., Doyle J., et al. 2013. Phylogeny drives large scale patterns in Australian marine bioactivity and provides a new chemical ecology rationale for future biodiscovery. PLoS ONE 8: e73800. http://dx.doi.org/10.1371/journal.pone.0073800

Fan L., Reynolds D., Liu M., et al. 2012. Functional equivalence and evolutionary convergence in complex communities of microbial sponge symbionts. Proc. Natl. Acad. Sci. USA 109: E1878-E1887. http://dx.doi.org/10.1073/pnas.1203287109

Fan L., Liu M., Simister R., et al. 2013. Marine microbial symbiosis heats up: the phylogenetic and functional response of a sponge holobiont to thermal stress. ISME J. 7: 991-1002. http://dx.doi.org/10.1038/ismej.2012.165

Faulkner D.J. 2000. Highlights of marine natural products chemistry (1972-1999). Nat. Prod. Rep. 17: 1-6. http://dx.doi.org/10.1039/a909113k

Freeman C.J., Gleason D.F. 2012. Does concentrating chemical defenses within specific regions of marine sponges result in enhanced protection from predators? Hydrobiologia 687: 289-297. http://dx.doi.org/10.1007/s10750-011-0792-3

Freeman C.J., Thacker R.W., Baker D.M., et al. 2013. Quality or quantity: is nutrient transfer driven more by symbiont identity and productivity than by symbiont abundance? ISME J. 7: 1116-1125. http://dx.doi.org/10.1038/ismej.2013.7

Garfield E. 1964. "Science Citation Index" - a new dimension in indexing. Science 144: 649-654. http://dx.doi.org/10.1126/science.144.3619.649

Garfield E. 1970. Citation indexing for studying science. Nature 227: 669-671.

http://dx.doi.org/10.1038/227669a0

Genta-Jouve G., Thomas O.P. 2012. Sponge chemical diversity: from biosynthetic pathways to ecological roles. In: Becerro M.A., Uriz M.J., Maldonado M., et al. (eds), Advances in Sponge Science: Physiology, Chemical and Microbial Diversity, Biotechnology, Vol 62. Academic Press, pp. 183-230. http://dx doi.org/10.1016/B978-0-12-394283-8.00004-7

Giribet G., Dunn C.W., Edgecombe G.D., et al. 2007. A modern look at the Animal Tree of Life. Zootaxa 1668: 61-79.

Gochfeld D.J., Kamel H.N., Olson J.B., et al. 2012. Trade-offs in defensive metabolite production but not ecological function in healthy and diseased sponges. J. Chem. Ecol. 38: 451-462. http://dx.doi.org/10.1007/s10886-012-0099-5

Green G. 1977. Ecology of toxicity of sponges. Mar. Biol. 40: 207-215. http://dx.doi.org/10.1007/BF00390876

Grozdanov L., Hentschel U. 2007. An environmental genomics perspective on the diversity and function of marine spongeassociated microbiota. Curr. Opin. Microbiol. 10: 215-220. http://dx.doi.org/10.1016/j.mib.2007.05.012

Halanych K.M. 2004. The new view of animal phylogeny. Annu. Rev. Ecol. Evol. Syst. 35: 229-256. http://dx.doi.org/10.1146/annurev.ecolsys.35.112202.130124

Hardoim C.C.P., Costa R. 2014. Temporal dynamics of prokaryotic communities in the marine sponge Sarcotragus spinosulus. Mol. Ecol. 23: 3097-3112. http://dx.doi.org/10.1111/mec.12789

Hardoim C.C.P., Cardinale M., Cúcio A.C.B., et al. 2014. Effects of sample handling and cultivation bias on the specificity of bacterial communities in keratose marine sponges. Front. Microbiol. 5 . http://dx.doi.org/10.3389/fmicb.2014.00611

Hentschel U., Piel J., Degnan S.M., et al. 2012. Genomic insights into the marine sponge microbiome. Nat. Rev. Microbiol. 10: 641-675. http://dx.doi.org/10.1038/nrmicro2839

Hill M.S. 1996. Symbiotic zooxanthellae enhance boring and growth rates of the tropical sponge Anthosigmella varians forma varians. Mar. Biol. 125: 649-654. http://dx.doi.org/10.1007/BF00349246

Hirsch J.E. 2005. An index to quantify an individual's scientific research output. Proc. Natl. Acad. Sci. USA 102: 16569-16572. http://dx.doi.org/10.1073/pnas.0507655102

Hochmuth T., Niederkruger H., Gernert C., et al. 2010. Linking chemical and microbial diversity in marine sponges: Possible role for Poribacteria as producers of methyl-branched fatty acids. ChemBioChem 11: 2572-2578. http://dx.doi.org/10.1002/cbic.201000510

Hooper J.N.A., van Soest R.W.M. 2002. Systema Porifera: a guide to the classification of sponges. Kluwer Academic/Plenum Publishers, New York, NY, USA. http://dx.doi.org/10.1007/978-1-4615-0747-5

Hunting E.R., de Goeij J.M., Asselman M., et al. 2010. Degradation of mangrove-derived organic matter in mangrove associated sponges. Bull. Mar. Sci. 86: 871-877. http://dx.doi.org/10.5343/bms.2010.1001

Indraningrat A., Smidt H., Sipkema D. 2016. Bioprospecting sponge-associated microbes for antimicrobial compounds. Mar. Drugs 14: 87 .

http://dx.doi.org/10.3390/md14050087

Ivanisevic J., Thomas O.P., Pedel L., et al. 2011. Biochemical trade- 
offs: Evidence for ecologically linked secondary metabolism of the sponge Oscarella balibaloi. PLoS ONE 6: e28059. http://dx.doi.org/10.1371/journal.pone.0028059

Jackson D.J., Thiel V., Worheide G. 2010. An evolutionary fasttrack to biocalcification. Geobiology 8: 191-196. http://dx.doi.org/10.1111/j.1472-4669.2010.00236.x

Jimenez E., Ribes M. 2007. Sponges as a source of dissolved inorganic nitrogen: Nitrification mediated by temperate sponges. Limnol. Oceanogr. 52: 948-958. http://dx.doi.org/10.4319/lo.2007.52.3.0948

Kampa A., Gagunashvili A.N., Gulder T.A.M., et al. 2013. Metagenomic natural product discovery in lichen provides evidence for a family of biosynthetic pathways in diverse symbioses. Proc. Natl. Acad. Sci. USA 110: E3129-E3137. http://dx.doi.org/10.1073/pnas.1305867110

König G.M., Kehraus S., Seibert S.F., et al. 2006. Natural products from marine organisms and their associated microbes. ChemBioChem 7: 229-238. http://dx.doi.org/10.1002/cbic.200500087

Leal M.C., Madeira C., Brandao C.A., et al. 2012a. Bioprospecting of marine invertebrates for new natural products - A chemical and zoogeographical perspective. Molecules 17: 9842-9854. http://dx.doi.org/10.3390/molecules 17089842

Leal M.C., Puga J., Serodio J., et al. 2012b. Trends in the discovery of new marine natural products from invertebrates over the last two decades - Where and what are we bioprospecting? PLoS ONE 7: e30580. http://dx.doi.org/10.1371/journal.pone.0030580

Lee O.O., Wang Y., Yang J., et al. 2011. Pyrosequencing reveals highly diverse and species-specific microbial communities in sponges from the Red Sea. ISME J. 5: 650-664. http://dx.doi.org/10.1038/ismej.2010.165

McClintock J.B., Amsler C.D., Baker B.J., et al. 2005. Ecology of Antarctic marine sponges: An overview. Integr. Comp. Biol. 45: 359-368. http://dx.doi.org/10.1093/icb/45.2.359

Moore B.S. 2006. Biosynthesis of marine natural products: macroorganisms (Part B). Nat. Prod. Rep. 23: 615-629. http://dx.doi.org/10.1039/b508781n

Müller W.E.G., Grebenjuk V.A., Le Pennec G., et al. 2004. Sustainable production of bioactive compounds by sponges - cell culture and gene cluster approach: a review. Mar. Biotechnol. 6: $105-117$. http://dx.doi.org/10.1007/s10126-002-0098-6

Newbold R.W., Jensen P.R., Fenical W., et al. 1999. Antimicrobial activity of Caribbean sponge extracts. Aquat. Microb. Ecol. 19: 279-284.

http://dx.doi.org/10.3354/ame019279

Nuñez-Pons L., Carbone M., Paris D., et al. 2012. Chemo-ecological studies on hexactinellid sponges from the Southern Ocean. Naturwissenschaften 99: 353-368. http://dx.doi.org/10.1007/s00114-012-0907-3

Paul V.J., Arthur K.E., Ritson-Williams R., et al. 2007. Chemical defenses: From compounds to communities. Biol. Bull. 213: 226-251. http://dx.doi.org/10.2307/25066642

Paul V.J., Ritson-Williams R., Sharp K. 2011. Marine chemical ecology in benthic environments. Nat. Prod. Rep. 28: 345-387. http://dx.doi.org/10.1039/C0NP00040J

Pawlik J.R., Chanas B., Toonen R.J., et al. 1995. Defenses of Caribbean sponges against predatory reef fish. I. Chemical deterrency. Mar. Ecol. Prog. Ser. 127: 183-194. http://dx.doi.org/10.3354/meps127183

Pawlik J.R., Loh T.L., McMurray S.E., et al. 2013. Sponge communities on Caribbean coral reefs are structured by factors that are top-down, not bottom-up. PLoS ONE 8: e6257. http://dx.doi.org/10.1371/journal.pone.0062573

Penesyan A., Marshall-Jones Z., Holmstrom C., et al. 2009. Antimicrobial activity observed among cultured marine epiphytic bacteria reflects their potential as a source of new drugs. FEMS Microbiol. Ecol. 69: 113-124 http://dx.doi.org/10.1111/j.1574-6941.2009.00688.x

Penesyan A., Kjelleberg S., Egan S. 2010. Development of novel drugs from marine surface associated microorganisms. Mar. Drugs 8: 438-459. http://dx.doi.org/10.3390/md8030438

Proksch P., Putz A., Ortlepp S., et al. 2010. Bioactive natural products from marine sponges and fungal endophytes. Phytochem. Rev. 9: 475-489.

http://dx.doi.org/10.1007/s11101-010-9178-9
Ravallion M., Wagstaff A. 2011. On measuring scholarly influence by citations. Scientometrics $88: 321-337$ http://dx.doi.org/10.1007/s11192-011-0375-0

Roper K.E., Beamish H., Garson M.J., et al. 2009. Convergent antifouling activities of structurally distinct bioactive compounds synthesized within two sympatric Haliclona demosponges. Mar. Biotechnol. 11: 188-198. http://dx.doi.org/10.1007/s10126-008-9132-7

Rützler K. 2012. The role of sponges in the Mesoamerican Barrier Reef ecosystem, Belize. In: Becerro M.A., Uriz M.J., Maldonado M., et al. (eds), Advances in Sponge Science: Phylogeny, Systematics, Ecology, Academic Press, Vol 61: 211-271. http://dx.doi.org/10.1016/B978-0-12-387787-1.00002-7

Sacristán-Soriano O., Banaigs B., Becerro M.A. 2011a. Relevant spatial scales of chemical variation in Aplysina aerophoba. Mar. Drugs 9: 2499-2513. http://dx.doi.org/10.3390/md9122499

Sacristán-Soriano O., Banaigs B., Casamayor E.O., et al. 2011b. Exploring the links between natural products and bacterial assemblages in the sponge Aplysina aerophoba. Appl. Environ. Microbiol. 77: 862-870. http://dx.doi.org/10.1128/AEM.00100-10

Sacristán-Soriano O., Banaigs B., Becerro M.A. 2012. Temporal trends in the secondary metabolite production of the sponge Aplysina aerophoba. Mar. Drugs 10: 677-693. http://dx.doi.org/10.3390/md10040677

Schippers K.J., Sipkema D., Osinga R., et al. 2012. Cultivation of sponges, sponge cells and symbionts: Achievements and future prospects. In: Becerro M.A., Uriz M.J., Maldonado M., et al. (eds) Advances in Sponge Science: Physiology, Chemical and Microbial Diversity, Biotechnology. Academic Press, Vol 62: 273-337. http://dx.doi.org/10.1016/B978-0-12-394283-8.00006-0

Schlappy M.L., Schottner S.I, Lavik G., et al. 2010. Evidence of nitrification and denitrification in high and low microbial abundance sponges. Mar. Biol. 157: 593-602. http://dx.doi.org/10.1007/s00227-009-1344-5

Schreiber M. 2013. A case study of the arbitrariness of the h-index and the highly-cited-publications indicator. J. Informetrics 7 : 379-387. http://dx.doi.org/10.1016/j.joi.2012.12.006

Schutze J., Krasko A., Custodio M.R., et al. 1999. Evolutionary relationships of Metazoa within the eukaryotes based on molecular data from Porifera. Proc. R. Soc. B 266: 63-73. http://dx.doi.org/10.1098/rspb.1999.0605

Siegl A., Bayer K., Kozytska S., et al. 2008. Sponges and Microbes - New frontiers in an ancient symbiosis. Vie Milieu-Life and Environment 58: 165-174.

Sipkema D., Franssen M.C.R., Osinga R., et al. 2005. Marine sponges as pharmacy. Mar. Biotechnol. 7: 142-162. http://dx.doi.org/10.1007/s10126-004-0405-5

Sokal R.R., Rohlf F.J. 1995. Biometry: The principles and practice of statistics in biological research, Freeman W. H. and Co., New York, NY, USA.

Taylor M.W., Radax R., Steger D., et al. 2007. Sponge-associated microorganisms: Evolution, ecology, and biotechnological potential. Microbiol. Mol. Biol. Rev. 71: 295-347. http://dx.doi.org/10.1128/MMBR.00040-06

Thacker R., Freeman C.J. 2012. Sponge-microbe symbioses: Recent advances and new directions. In: Becerro M.A., Uriz M.J., Maldonado M., et al. (eds) Adv Mar Biol. 62: 57-111. Academic Press. http://dx.doi.org/10.1016/b978-0-12-394283-8.00002-3

Thomas T.R.A., Kavlekar D.P., LokaBharathi P.A. 2010a. Marine drugs from sponge-microbe association - a review. Mar. Drugs 8: $1417-1468$ http://dx.doi.org/10.3390/md8041417

Thomas T., Rusch D., DeMaere M.Z., et al. 2010b. Functional genomic signatures of sponge bacteria reveal unique and shared features of symbiosis. ISME J. 4: 1557-1567. http://dx.doi.org/10.1038/ismej.2010.74

Thomson and Reuters. 2014. Web of Knowledge. http://webofknowledge.com (accessed 29 Jan 2015).

Uriz M.J., Agell G., Blanquer A., et al. 2012. Endosymbiotic calcifying bacteria: A new cue to the origin of calcification in Metazoa? Evolution 66: 2993-2999. http://dx.doi.org/10.1111/j.1558-5646.2012.01676.x

van Soest R.W.M., Boury-Esnault N., Vacelet J., et al. 2012. Global diversity of sponges (Porifera). PLoS ONE 7: e35105. http://dx.doi.org/10.1371/journal.pone.0035105 
Waltman L., van Eck N.J. 2012. The inconsistency of the h-index. J. Amer. Soc. Inform. Sci. Technol. 63: 406-415.

http://dx.doi.org/10.1002/asi.21678

Waltman L., van Eck N.J. 2013. Source normalized indicators of citation impact: an overview of different approaches and an empirical comparison. Scientometrics 96: 699-716. http://dx.doi.org/10.1007/s11192-012-0913-4

Wang G.Y. 2006. Diversity and biotechnological potential of the sponge-associated microbial consortia. J. Ind. Microbiol. Biotechnol. 33: 545-551. http://dx.doi.org/10.1007/s10295-006-0123-2

Webster N.S., Xavier J.R., Freckelton M. et al. 2008. Shifts in microbial and chemical patterns within the marine sponge Aplysina aerophoba during a disease outbreak. Environ. Microbiol. 10: 3366-3376.

http://dx.doi.org/10.1111/j.1462-2920.2008.01734.x

Webster N.S., Taylor M.W., Behnam F., et al. 2010. Deep sequencing reveals exceptional diversity and modes of transmission for bacterial sponge symbionts. Environ. Microbiol. 12: 2070-2082.

Webster N., Pantile R., Botte E., et al. 2013a. A complex life cycle in a warming planet: gene expression in thermally stressed sponges. Mol. Ecol. 22: 1854-1868. http://dx.doi.org/10.1111/mec.12213
Webster N.S., Luter H.M., Soo R.M., et al. 2013b. Same, same but different: symbiotic bacterial associations in GBR sponges. Frontiers in Microbiology 3: 444 http://dx.doi.org/10.3389/fmicb.2012.00444

Wilkinson C.R. 1984. Immunological evidence for the Precambrian origin of bacterial symbioses in marine sponges. Proc. R. Soc. B 220: 509-517. http://dx.doi.org/10.1098/rspb.1984.0017

Wright A.D., McCluskey A., Robertson M.J., et al. 2011. Antimalarial, anti-algal, anti-tubercular, anti-bacterial, anti-photosynthetic, and anti-fouling activity of diterpene and diterpene isonitriles from the tropical marine sponge Cymbastela hooperi. Org. Biomol. Chem. 9: 400-407. http://dx.doi.org/10.1039/C0OB00326C

Wulff J.L. 2006. Ecological interactions of marine sponges. Can. J. Zool. 84: 146-166. http://dx.doi.org/10.1139/z06-019

Wulff J. 2012. Ecological interactions and the distribution, abundance, and diversity of sponges. In: Becerro M.A., Uriz M.J., Maldonado M., et al. (eds), Advances in Sponge Science: Phylogeny, Systematics, Ecology, Academic Press, Vol 61: 273-344.

http://dx.doi.org/10.1016/B978-0-12-387787-1.00003-9 